\title{
Mouse Model for the Research of Sinusitis Induced Olfactory Dysfunction
}

\author{
Yong Gi Jung \\ Department of Otorhinolaryngology-Head and Neck Surgery, Samsung Changwon Hospital, \\ Sungkyunkwan University School of Medicine, Changwon, Korea
}

\section{부비동염에 의해 유발된 후각소실 연구를 위한 생쥐 모델}

정 용 기

성균관대학교 의과대학 삼성창원병원 이비인후과학교실

Received June 26, 2015 Accepted July 20, 2015 Address for correspondence Yong Gi Jung, MD, PhD Department of OtorhinolaryngologyHead and Neck Surgery, Samsung Changwon Hospital, Sungkyunkwan University School of Medicine, 158 Paryong-ro, Masanhoewon-gu, Changwon 51353, Korea

Tel +82-55-290-6066

Fax +82-55-290-6465

E-mail ent.jyg@gmail.com
Olfactory dysfunction is one of the most debilitating problem in chronic rhinosinusitis (CRS) patients, and exact mechanism underlying sinusitis induced olfactory dysfunction was not fully understood. In vivo manipulation for olfactory epithelium and fresh specimen for histopathological analysis are essential for research, but it is nearly impossible to do in human due to inaccessibility of olfactory epithelium and risk for complication. For this reason, several animal models using toxic materials, such as 3-methylindole or bromomethane, have been suggested for mimicking olfactory epithelial damage in CRS, but none of them could truly imitate the event which happens in real patient. Inducible olfactory inflammation (IOI) mouse is a transgenic mouse model selectively producing tumor necrosis factor-alpha (TNF- $\alpha$ ) in sustentacular cell of olfactory epithelium. The production of TNF- $\alpha$ can be actively initiated by giving food containing doxycycline to IOI mouse, and inflammation is stopped in the absence of doxycycline. Both toxicity model and transgenic model have their own advantages and disadvantages, therefore appropriate model should be selected for optimal results.

Korean J Otorhinolaryngol-Head Neck Surg 2015;58(12):815-21

Key Words 3-methylindole $\cdot$ Bromomethane $\cdot$ Doxycycline $\cdot$ Mice $\cdot$ Olfaction $\cdot$ Sinusitis · Transgenic animal $\cdot$ Tumor necrosis factor.

\section{서 론}

만성 부비동염의 유병률은 높게는 $14 \%$ 까지 보고되고 있으 며 동반되는 주요 증상으로 코 막힘, 화농성 비루 또는 후비 루 등이 있고 후각저하 및 부비동 주변 통증 등이 발생하기 도 한다. ${ }^{1)}$ 이러한 증상들의 대부분은 적절한 약물을 투여하 고 필요한 경우 수술적 치료를 시행하면 호전될 수 있다. 그 러나 후각저하 또는 후각소실의 경우 만성 부비동염 환자의 25 30\%에서 증상을 호소하며, 부비동 내시경수술을 시행 받는 환자의 경우 그 비율이 $80 \%$ 에 달한다고 알려져 있지만 치료 후 후각기능이 호전되지 않는 경우도 많고, 부비동염이 치료되었을 때 후각개선의 정도를 예측하기 어렵다. ${ }^{2-4)}$
후각저하가 발생하는 이유는 크게 3가지로 나눌 수 있다. 비용종, 분비물이나 점막 부종에 의해 후각물질(odorant)이 후각상피(olfactory epithelium)에 도달하는 통로가 막히거 나, 후각상피에 손상이 발생하여 후각물질을 제대로 인지하 지 못하고, 후각상피에서 발생한 전기적 신호가 사상판(cribriform plate)을 지나 후구(olfactory bulb)를 거쳐 중추신경 계로 전달되지 못할 때 발생한다. ${ }^{4,5)}$ 만성 부비동염의 경우 위 에 나열한 3 가지 이유 중 앞의 두 가지 이유가 후각저하의 주 요 원인이며 특히 후각상피의 손상 여부가 부비동염 치료 후 후각기능 호전에 영향을 주는 중요한 인자가 된다. ${ }^{6)}$ 그러나 임상적으로 후각상피 손상을 예측하기가 어려우며 후각상피 의 손상 기전에 대해서 밝혀지지 않은 부분이 많다. 이러한 문 
제에 답을 제시하기 위해 만성 부비동염과 후각상피의 손상 의 연관성에 대한 연구들이 진행되어 왔으나 아직도 실제 환 자들에게 적용시킬 수 있는 연구 결과는 많지 않다.

인간을 대상으로 한 후각연구를 시행하는 것은 비용종이 나 호흡상피와 같은 부비강내 다른 영역의 연구를 시행하는 것과 비교할 때 몇 가지 큰 제한점을 가지고 있다. 인간의 경우 후각상피의 범위가 극히 제한되어 있고 개인마다 위치의 차이 가 있어 필요한 조직을 얻기가 어려우며, 피험자에게 기능적 또는 의학적 문제를 발생시키지 않으며 얻을 수 있는 검체의 양 또한 매우 적다. 실제로 부비동 내시경수술 중 얻어진 상 비갑개 점막을 후각상피의 특징적인 표지자인 후각표지단백 (olfactory marker protein, OMP)을 이용하여 면역조직화학 (immunohistochemistry)염색을 시행하였을 때 OMP가 확인 되는 조직을 얻을 수 있는 확률은 높지 않다. ${ }^{7)}$ 이러한 이유로 인체 대신 동물을 대상으로 하는 연구들이 고안되어 진행되 어 왔고, 인체와 비슷한 미세구조의 후각상피조직을 가지고 있으며 비강면적 대비 후각상피의 면적이 매우 넓은 동물인 생쥐(mouse)를 이용한 모델들이 소개되었다.

본 논문에서는 최근 각광받고 있는 유전자조작(transgenic) 후각소실 생쥐 모델을 포함한 여러 후각소실 모델들을 소개 하고 연구를 시행함에 있어서 각 생쥐 모델의 장단점을 알아 보고자 한다.

\section{본 론}

\section{포유류 후각상피의 구조}

후각상피의 손상을 이해하기 위해서 먼저 후각상피의 구조 를 파악할 필요가 있다. 인간의 후각상피는 상비갑개 상부, 중비갑개 내측 및 비중격의 최상부에 존재하며 면적은 1 2 $\mathrm{cm}^{2}$ 정도로 전체 비강점막 대비 극히 일부분에 존재한다. ${ }^{8)}$ 그러나 생쥐와 같은 설치류의 경우 4개의 후각 갑개(olfactory turbinate)를 가지고 있으며 비강점막의 후방 $1 / 2$ 이상을 후 각상피가 차지하고 있어 후각연구에 매우 용이하다.

후각상피의 두께는 60 70 $\mu \mathrm{m}$ 로 일반적인 호흡상피보다 두꺼워 현미경 시야에서 구분할 수 있으며 미세융모세포 (microvilli cell), 지지세포(supporting cell, sustentacular cell), 후각수용세포(olfactory receptor cell or neuron, ORN), 구형기저세포(globose basal cell), 그리고 판형기저세포 (horizontal basal cell)로 구성되어 있다. 후각상피연구에서 가장 먼저 주목하는 세포는 ORN으로 OMP를 발현하기 때 문에 면역조직화학염색에서 확인할 수 있어 후각상피의 신 경조직 손상 여부를 판단하는 1 차 도구로 사용된다. ${ }^{9}$ 지지세 포는 후각상피의 전층에 걸쳐 존재하는 원주형의 세포로 기 저막(basement membrane)으로 가까이 갈수록 가늘어지는 형태를 보인다. 지지세포는 주변의 ORN이 정상적인 세포기 능을 유지할 수 있도록 이온과 물을 조절하는 역할을 한다고 알려져 있으며, ${ }^{10)}$ Bowman씨 샘(Bowman's gland)과 함께 작 용하여 후각물질과 같이 상피에 접촉한 외부물질의 대사에 관여한다. 지지세포는 S-100 또는 cytokeratin-18을 표식자 로 하는 면역조직화학염색을 시행하여 확인할 수 있다. 기저세 포는 고유층(lamina propria) 바로 위에 존재하는 세포로 판 형 기저세포가 가장 밑에 존재하며 그 위에 구형기저세포가 위치한다. 후각상피는 인체에서 유일하게 재생이 가능한 신 경이라는 특성 때문에 많은 신경조직연구의 대상이 되며 기저 세포가 이러한 재생기능을 담당하는 것으로 알려져 있어 줄기 세포로 여겨지기도 한다. ${ }^{11}$ 판형기저세포는 keratin 5 , keratin 14 , intercellular adhesion molecule-1 등의 표식자를 이용 하여 염색할 수 있으며, ${ }^{12)}$ 구형기저세포의 경우 적합한 표식자 가 없어서 연구가 어려웠으나 최근 leucine-rich repeat containing $\mathrm{G}$ protein-coupled receptor-5라는 표식자가 발견 되었다. 염증이나 기계적 외상으로 인하여 후각상피의 일부 에 국한된 손상이 발생한 경우 구형기저세포가 증식을 하여 각각의 세포로 분화하여 후각상피회복을 유도하며, 상피층 의 대부분이 소실될 정도로 큰 손상이 발생한 경우 판형기저 세포가 증식하여 구형기저세포를 포함한 후각상피 조직의 재생을 담당한다고 알려져 있다. ${ }^{13)}$

\section{Toxicity model}

인체에서 발생하는 후각상피 손상을 모방하기 위해 가장 먼저 사용되기 시작한 동물 모델은 독성 모델(toxicity model) 로 후각상피를 선택적으로 손상시키거나 다른 조직보다 먼 저 손상시키는 물질을 호흡기로 흡입시키거나 복강내로 주입 하여 상피에 직접적인 손상을 가한다. 1988년 Hurtt 등 ${ }^{14)}$ 은 F-344 쥐에 methyl bromide를 5일 동안 호흡기를 통하여 노출시킨 후 시간에 따른 후각상피의 손상과 회복과정을 연 구하여 methyl bromide에 의한 후각소실 생쥐 모델을 처음 소개하였고 이후 여러 논문에서 사용되어 왔다. ${ }^{15,16)}$ Methyl bromide의 화학식 명칭은 bromomethane으로 $\mathrm{CH}_{3} \mathrm{Br}$ 의 구 조로 되어 있는 무색, 무취, 비발화성 기체이며 2000년대 초기 까지 여러 나라에서 농업용 살충제로 사용되었던 물질이다. 인 체가 노출되었을 경우 호흡, 신장, 신경독성을 유발한다고 알 려져 있지만 이러한 특성 때문에 적정 농도에서 후각상피에 선택적 손상을 유발할 수 있다는 것이 알려졌고 동물에 쉽게 적용시킬 수 있기 때문에 많은 연구에서 사용되었다. ${ }^{14,17-19)}$

Bromomethane 이외에 많이 사용된 물질로는 3-methylindole(3-MI)이 있다. 3-MI는 skatole이라고도 불리며 tryp- 
tophan 대사체이고 포유류 소화기에서 생성되어 특유의 독 한 냄새를 가지고 있다. $\mathrm{C}_{9} \mathrm{H}_{9} \mathrm{~N}$ 의 구조로 되어 있으며 백색의 수정형태를 띠는 물질로 ${ }^{20)}$ 벌이나 모기와 같은 곤충을 유혹 하는 미끼물질로 사용된다. ${ }^{21)}$ 포유류가 3-MI에 노출되었을 때 폐 부종(pulmonary edema) 또는 폐기종(emphysema)이 유발 되는 것으로 보고되었으며 설치류에 저농도로 투입하였을 경우 비강내의 호흡상피에는 영향을 주지 않고 선택적으로 후각상피에 손상을 준다. ${ }^{22-24)} 3-\mathrm{MI}$ 는 bromomethane과는 다르게 주로 복강내로 주입하며 위와 같은 특성 때문에 설치 류를 이용한 후각상피 손상 실험에서 많이 사용되어 왔다. $25-28)$

그러나 bromomethane이나 3-MI에 의한 후각상피 손상 모델은 설치류를 이용한 실험에서 쉽게 적용할 수 있는 장점 은 있으나, 만성 부비동염에서 후각상피 손상이 발생하는 기 전으로 여겨지는 염증물질에 의한 상피 손상과 이에 따른 세 포자멸(apoptosis) 등의 기전이 아니라 ${ }^{29}$ 독성물질에 의한 세 포괴사를 유발하기 때문에 부비동염에 의한 후각소실 모델 로 사용하기에는 부적합하다. 또한 약제 투입 후 즉각적인 광 범위 세포탈락이 발생하기 때문에 염증반응의 정도(doseresponse)를 조절하기 어렵고 시간에 따른 단계적 변화 양상 을 관찰할 수 없다. 따라서 독성 모델은 후각상피 손상의 기전 을 밝히는 연구보다는 손상을 방지하는 기전 또는 물질에 대 한 연구, 그리고 손상 후 회복을 촉진시키는 방법이나 약제에 대한 연구에 적합하다고 할 수 있다. ${ }^{26)}$

\section{Transgenic model}

후각상피에 대한 이전의 연구들은 만성 부비동염에 의한 후각소실이 후각상피 내부의 염증반응에 의해 발생하며 염 증이 지속될 경우 후각상피가 손상되어 정상조직으로의 재생 이 억제되고 추후 호흡상피로 대체될 수 있다고 보고하였다. ${ }^{29)}$ 그러나 상피손상의 최종단계가 아닌 초기 손상의 경우 후각 상피에 발생한 염증과 이에 의한 손상은 스테로이드 등의 항 염증 치료에 의해 호전될 수 있으며 후각소실이 ORN을 포 함한 상피 자체의 손상에 의해 발생하기보다는 구조적 손상 이 발생하기 전 신경전달체계의 기능적 부전으로 발생하는 것으로 보고되고 있다. ${ }^{30)}$ 따라서 만성 부비동염에 의한 후각 소실이 발생하는 순차적인 과정을 연구하기에 기존에 알려진 독성 모델은 적합하지 않았으며, 이러한 제한점을 해결할 수 있고 실제로 부비동염이 있는 환자의 후각상피에서 일어나 는 현상을 모방할 수 있는 동물 모델이 필요했다.

2005년 Lane 등 ${ }^{31)}$ 은 만성 부비동염에서 발생하는 후각상 피 손상에 의한 후각소실을 모방하는 유전자 조작 모델의 개 념을 처음 제안하였고, 2010년 inducible olfactory loss(IOI) 생쥐 모델을 확립하여 이에 대한 연구 결과를 발표하였다. ${ }^{32}$
$\mathrm{IOI}$ 생쥐는 특정 유전자를 조작함으로써 후각상피에 선택적 으로 염증을 발생시키고 연구자가 원하는 기간만큼 유지하고 중단시킬 수 있는 특성을 가지고 있다. 만성 부비동염에서 발 생하는 후각상피 변화를 연구하는 데 있어 기존의 후각소실 모델과 다르게 염증에 관여하는 사이토카인 발현을 연구자가 의도적으로 조작할 수 있는 모델은 매우 중요한 의미를 가진 다. 첫째, 실제 인간의 경우 부비동염에 의한 후각소실은 기관 발달이 끝나지 않은 소아에서 발생하기보다 성장이 끝난 후 발생하는 것이 일반적이기 때문에 성장이 끝난 후 염증을 유 발함으로써 이러한 현상을 유사하게 재현할 수 있다. 둘째, 염 증성 사이토카인 유전자를 단순 삽입하여 항상 발현되도록 조작을 가할 경우 수정란 이후부터 지속적으로 사이토카인 이 발현되어 기관 발달에 영향을 주거나 정상적인 성장을 방 해할 수 있어 부비동염 모델로서의 가치를 잃게 된다. 마지막 으로 유전자 발현 기간을 선택적으로 조절함으로써 후각상피 가 염증성 사이토카인에 노출되는 용량을 조절할 수 있는 장 점이 있어 다양한 염증 단계의 연구를 진행할 수 있다. ${ }^{32}$

유전자조작 IOI 생쥐는 위의 조건에 부합하는 생쥐 모델로 후각상피에서 선택적으로 tumor necrosis factor-alpha(TNF$\alpha$ )를 분비하여 염증반응을 유발하며 이러한 염증을 연구자가 의도하는 대로 시작하고 중지할 수 있도록 조작되었다. IOI 생 쥐에 doxycycline이 포함된 사료(pellet)를 투여하면 후각상 피의 지지세포에서 선택적으로 TNF- $\alpha$ 가 생성되어 염증이 유 발된다. IOI 생쥐에 대한 보다 자세한 설명을 하기 위하여 전체 개념을 TNF- $\alpha$ 에 의한 염증반응, cyp2g1-reverse tetracycline transactivator(rtTA), 그리고 tetracycline response element(TRE)-TNF- $\alpha$ 에 이르는 세 부분으로 나누어 기술하고 자 한다.

\section{$\mathrm{TNF}-\alpha$}

부비동염의 염증반응에 관여하는 여러 매개물질 중 TNF$\alpha$ 는 가장 강력한 염증 유발물질 중 하나로 알려져 있으며 주 로 조직 손상과 리모델링에 관여한다. ${ }^{33,34)} \mathrm{TNF}-\alpha$ 는 cachexin 이라는 명칭으로도 알려있으며 사이토카인 자체도 염증반응 을 유발하지만 nuclear factor kappa B 대사과정을 통해 세포 의 증식 및 염증반응을 일으키고, Jun N-terminal kinase 대 사과정을 통해 세포 분화, 증식에 관여하며, caspase- 3 을 통 해 세포자멸을 유도하기도 한다(Fig. 1). ${ }^{35-37)}$ 이러한 TNF- $\alpha$ 가 후각점막에서 어떠한 역할을 하는지에 대해서는 아직 명 확하게 알려져 있지 않지만 생체 외(in vitro)실험에서 $\mathrm{TNF}-$ $\alpha$ 의 투여가 성숙된 ORN의 세포자멸을 유도하였다는 보고 가 있었다. ${ }^{38)}$ 


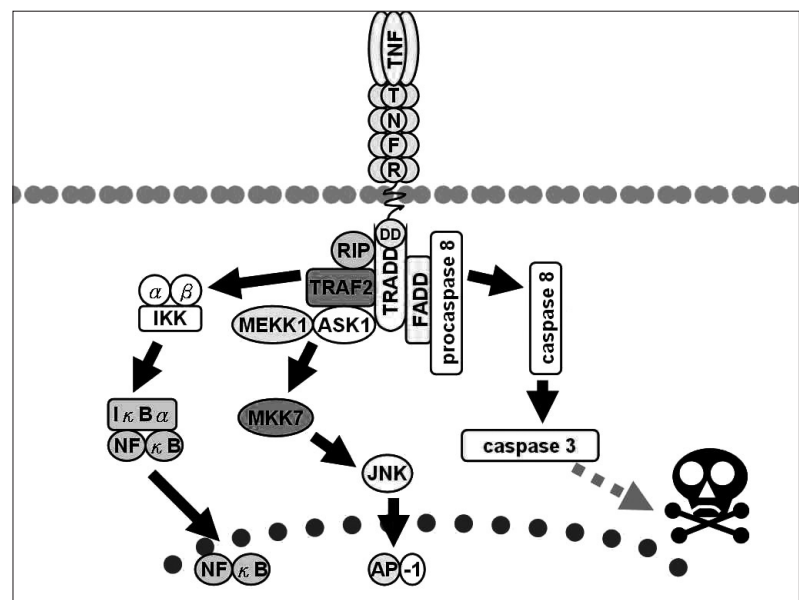

Fig. 1. Signaling pathway of tumor necrosis factor receptor 1 (TNFR1). There are three main sub-pathway following the binding of TNF- $\alpha$ to TNFR1. Dashed grey line following caspase 3 represents multiple step. TNF: tumor necrosis factor, JNK: Jun N-terminal kinase, RIP: receptor interacting protein, TRADD: TNF-associated death domain, FADD: fas-associated death domain, NF: Nuclear factor, TRAF: TNF receptor associated factor.

\section{Cyp2g1-rtTA}

후각상피의 지지세포에서 선택적으로 $\mathrm{TNF}-\alpha$ 를 생성하기 위해서는 해당 세포에만 선택적으로 존재하는 촉진유전자 (promoter)를 이용해야 한다. Cyp2g1은 후각특이 cytochrome $\mathrm{p} 450$ 유전자로 후각상피의 지지세포에 선택적으로 존재하여 이 유전자를 promoter로 삼아 그 뒤에 특정 유전자를 삽입 할 경우 해당 세포에서만 선택적인 사이토카인 생성을 유도할 수 있다. ${ }^{39)}$ 이러한 이유로 cyp2g1의 뒤에 rtTA 유전자를 상동 재조합(homologous recombination)을 통해 삽입한다. rtTA 는 일종의 Tet-on 시스템 단백으로 Escherichia coli에서 발견 된 tetracycline repressor과 herpes simplex virus의 VP16단 백의 융합에 의해 만들어졌다. 이 단백은 tetracycline 또는 대사체인 doxycycline이 존재할 때만 작동유전자(operator) 인 TRE에 붙을 수 있으며 tetracycline이 없으면 TRE에 붙 지 못해 연결되어 있는 유전자가 활성화되지 못한다. rtTA에 대한 촉진유전자로 ORN에 존재하는 유전자 대신 지지세포에 존재하는 유전자를 선택한 이유는 ORN 자체에서 TNF- $\alpha$ 를 생성할 경우 이것은 실제 부비동염에서 일어나는 현상과 다 르게 되며, 염증성 사이토카인이 주변의 부비동에서 생성되어 $\mathrm{ORN}$ 에 영향을 주는 것과 유사한 환경을 만들기 위해 지지세 포에 있는 cyp2g1을 선택하였다.

TRE-TNF- $\alpha$ and advantage of Tet-on system

$\mathrm{TRE}$ 는 rtTA에 반응하여 작동하는 유전자로 TRE와 TNF$\alpha$ 생성 유전자를 결합하여 이루어진 TRE-TNF- $\alpha$ 유전자 분 절을 생쥐 유전자 내에 무작위 삽입(random insertion)을 한

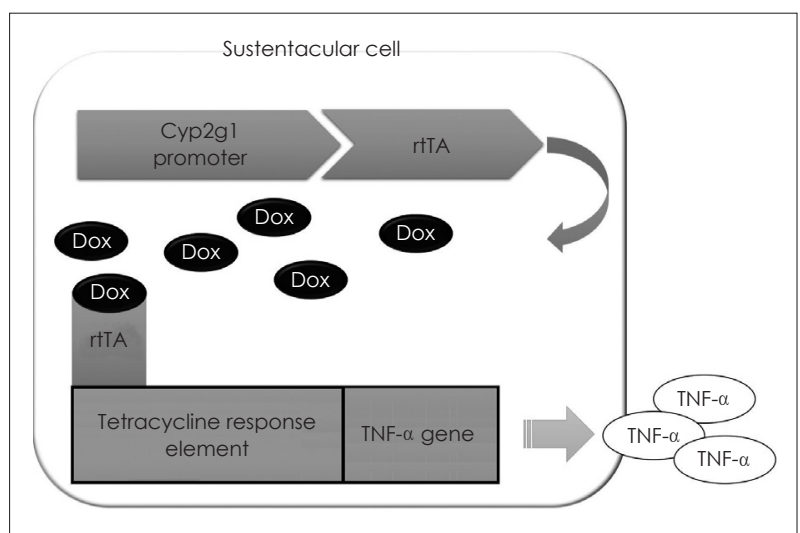

Fig. 2. Diagram of inducible olfactory inflammation mouse. Tet-on gene is knocked into the cyp2g1 locus as homologous insertion, resulting in cell-specific expression of reverse tetracycline transactivator (rtTA) in sustentacular cell of olfactory epithelium. Tetracycline response element introduced by random insertion is followed by tumor necrosis factor-alpha (TNF- $\alpha$ ) gene. TNF- $\alpha$ is expressed only in the presence of both rtTA and doxycycline (Dox).

다. 그리고 TRE-TNF- $\alpha$ 를 가지고 있는 생쥐를 위에 설명한 cyp2g1-rtTA 유전자를 가진 생쥐와 교배함으로써 cyp2g1$\mathrm{rtTA} / \mathrm{TRE}-\mathrm{TNF}-\alpha$ 유전자 조합을 갖춘 IOI mouse가 만들 어 진다(Fig. 2).

Tet-on 시스템을 사용한 IOI mouse는 기존의 유전자조작 방법인 Cre-Lox 재조합(recombination) 또는 estrogen receptor-tamoxifen 시스템에 비해 몇 가지 장점을 가지고 있 다. 기존의 시스템은 한 번 단백 유전자재조합이 일어나면 돌 이킬 수 없기 때문에 특정 유전자의 활성화나 녹아웃(knock out)이 영구적으로 일어난다. 따라서 연구자가 원한다고 해 도 이미 시작된 유전자 발현을 멈출 수가 없는 반면, IOI 생쥐 에서는 doxycycline을 사료에서 제거함으로써 손쉽게 TNF- $\alpha$ 의 발현을 중지시킬 수 있다.

\section{Research with IOI mouse}

이렇게 만들어진 IOI 생쥐를 이용하여 연구를 시행하기 위 해서 먼저 유전형분석(genotyping)을 시행하여 해당 유전자 가 생쥐 내에 존재하는지 확인해야 한다. 또한 유전자가 제대 로 작동하여 doxycycline을 투여하였을 때(Fig. 3) 후각상피 에서 $\mathrm{TNF}-\alpha$ 가 제대로 생성되는지 확인하게 되며 $250 \mu \mathrm{L}$ 의 phosphate buffered saline을 이용하여 비강 세척(nasal lavage)을 시행한 후 원심분리하고 상층액으로 enzyme linked immunosorbent assay를 시행하여 TNF- $\alpha$ 의 농도를 측정한 다. TNF- $\alpha$ 유전자가 없는 생쥐(wild type)이거나 doxycycline을 투여하지 않은 생쥐의 비강 세척액 내 TNF- $\alpha$ 의 농 도는 $10 \mathrm{pg} / \mathrm{mL}$ 이하이지만 염증반응이 유발된 경우 농도는 $100 \mathrm{pg} / \mathrm{mL}$ 이상으로 상승한다. ${ }^{32}$ 생후 8주가 지나면 성체로 판단하고 원하는 기간에 doxycycline을 포함한 사료를 투입 
하며 이후 필요한 실험을 진행할 수 있다. 염증을 유발하고 2 주가 경과하면 IOI 생쥐의 후각 기능이 저하된다. 생쥐의 후각 기능 분석을 위해 생쥐 후각상피 부분을 분리하여 electro olfactogram을 시행하여 측정할 수 있다(Fig. 4). 그러나 아직 이 시기는 후각상피의 형태적 변화는 발생하지 않으며 기능

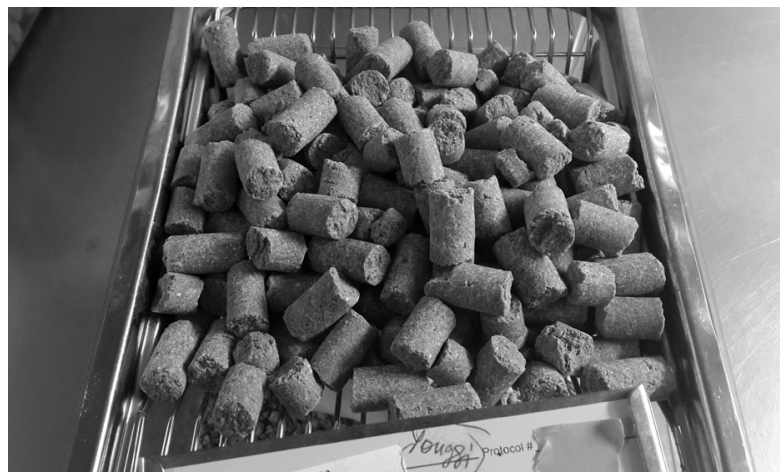

Fig. 3. Doxycycline pellet for inducible olfactory inflammation mouse (BiosServ, Flemington, NJ, USA). The dose of doxycycline is $200 \mathrm{mg} / \mathrm{kg}$.
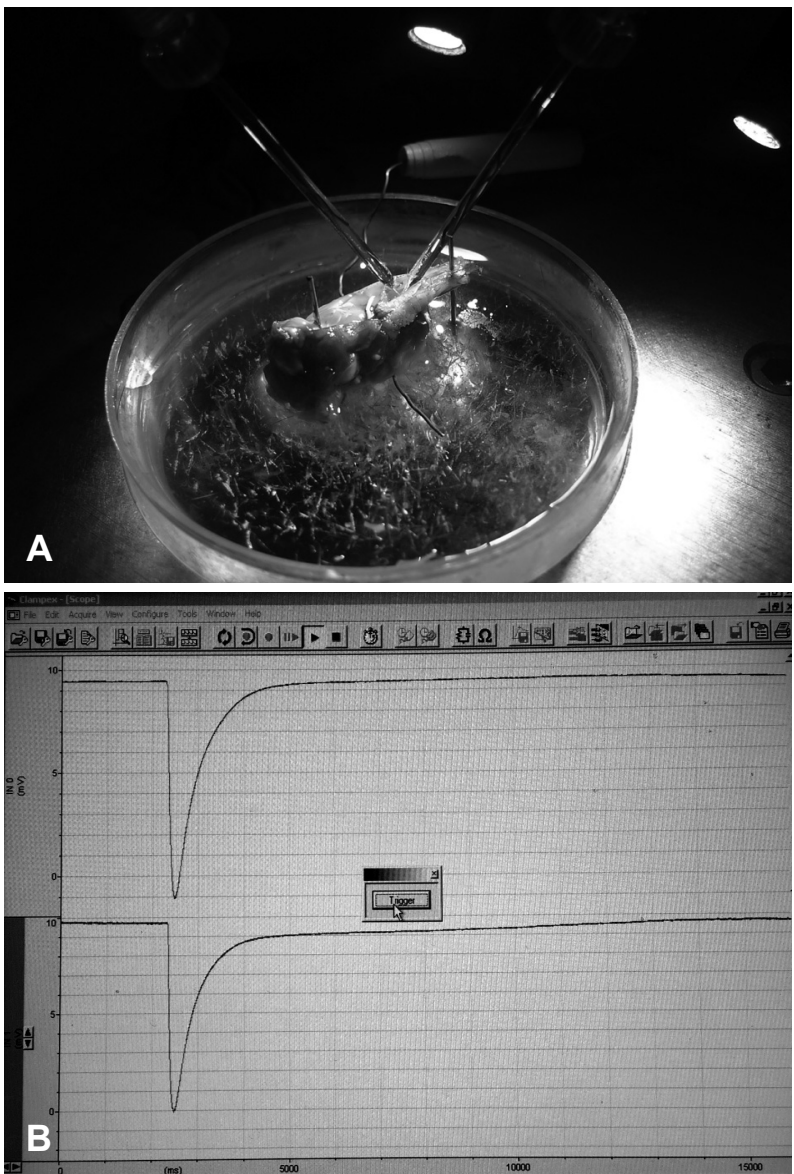

Fig. 4. The equipment for electro-olfactogram of mouse. After bisecting head of mouse, two electrodes were placed on mucus blanket of 2 nd and 3rd olfactory turbinate, and a ground electrode earths to Ringer lactate solution (A). Normal summation potential of olfactory turbinate in wild type mouse is about $10 \mathrm{mV}(B)$.
적 변화만 발생한다(Fig. 5). 염증을 4주간 계속 지속시키면 후각상피의 변화가 발생하기 시작하며 기저막하에 염증세포 의 침윤이 관찰되고 염증세포들에 의해 축삭이 눌려 작아지 게 되며 상피내 ORN의 크기도 따라서 감소한다. 6주가 지나 면 ORN을 포함한 상피내 세포들의 손상이 더욱 진행하여 상 피층이 매우 얇아지는 것을 관찰할 수 있다(Fig. 6). 이러한 과

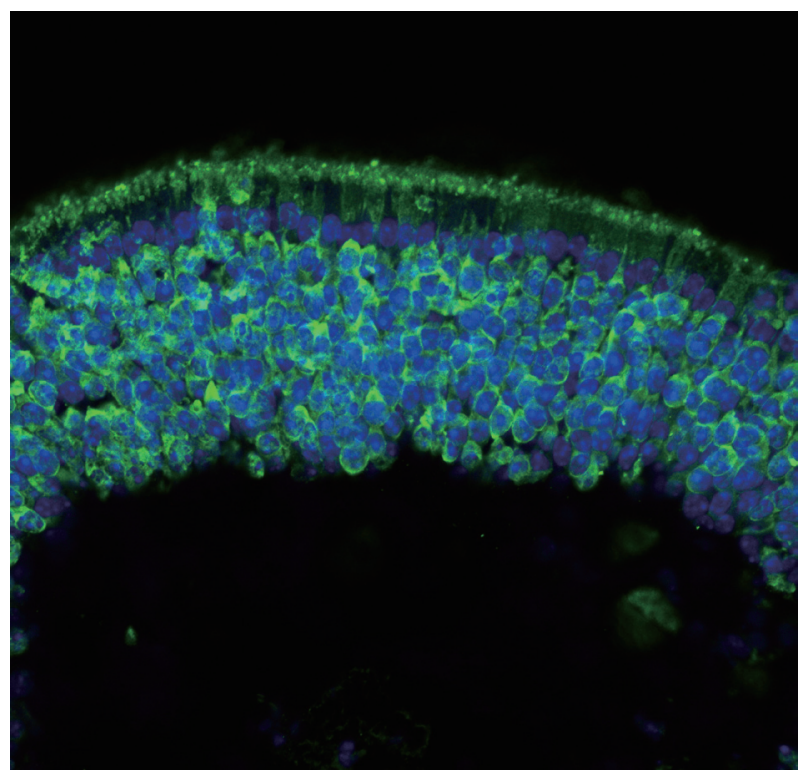

Fig. 5. Immunofluorescence on olfactory epithelium cryosection with anti-OMP and anti-DAPI (4',6-diamidino-2-phenylindole) antibody after 2 -weeks of induced inflammation in IOI mouse. The thickness of olfactory epithelium was not decreased $(\times 250)$. OMP: olfactory marker protein, IOI: inducible olfactory loss.

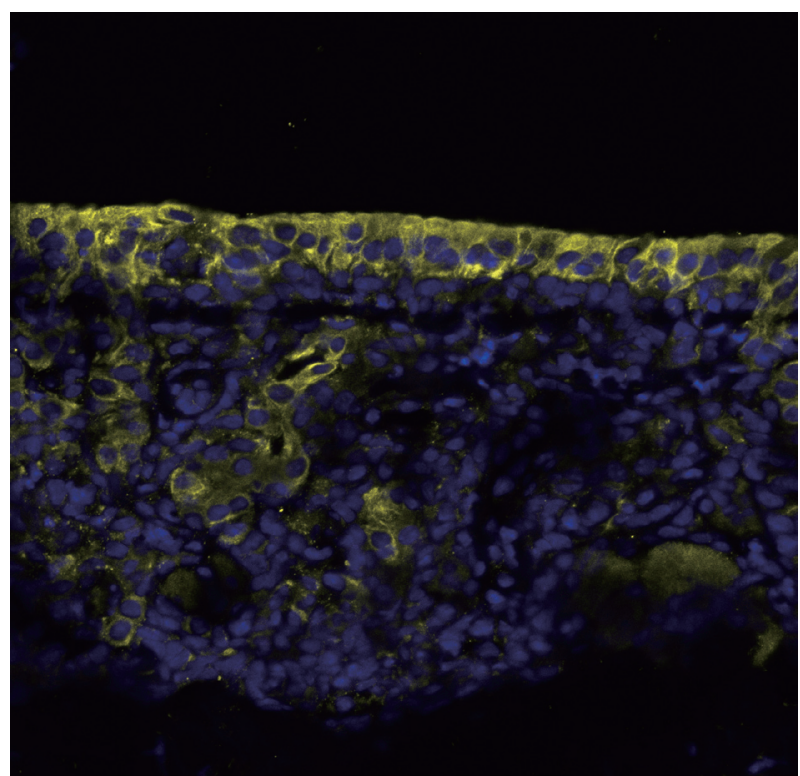

Fig. 6. Immunofluorescence on olfactory epithelium cryosection with anti-cytokeratin 18 and anti-DAPI (4',6-diamidino-2-phenylindole) antibody after 6 -weeks of induced inflammation in IOI mouse. The thickness of olfactory epithelium was significantly decreased $(\times 250)$. IOI: inducible olfactory loss. 
정에 세포자멸이 관여하게 되며 caspase 염색을 통해 확인할 수 있다.

\section{결 론}

인체에서 발생하는 여러 질환들을 이해하고 적절한 치료법 을 개발하기 위해서 해당 질환을 정확하게 모방하는 동물 모 델은 필수적이다. 후각상피는 신경조직임에도 불구하고 재생 이 가능한 특성 때문에 많은 연구의 대상이 되어 왔지만 부 비동염과 관련된 후각소실에 대한 연구보다는 후각초성세포 (olfactory ensheathing cell)나 신경세포 자체의 재생과 같은 연구에 보다 많은 관심이 기울여 졌었다. ${ }^{40-42)}$ 그러나 2000년대 에 들어서면서 신경조직으로서의 후각상피보다는 감각기관으 로서의 후각상피에 대한 연구들이 점차적으로 증가하고 있다.

$\mathrm{IOI}$ 생쥐는 $\mathrm{TNF}-\alpha$ 를 주요 사이토카인으로 설정하고 지지 세포를 대상세포로 하였다. 그러나 여기서 멈추지 않고 이러 한 유전자조작 디자인을 확대시키면 interleukin 등과 같은 염 증반응에 관여하는 다른 사이토카인을 생성하는 유전자를 삽입할 수 있으며 대상 세포 또한 연구자의 필요에 따라 바꿀 수도 있다. 이러한 의미에서 만성 부비동염에 따른 후각소실 을 연구하기 위한 유도형 동물 모델의 개발은 다양한 추가연 구를 시행할 수 있는 가능성을 열었다고 할 수 있다.

후각연구를 시행함에 있어서 가장 적합한 동물 모델을 선 택하는 것에 대해서 정답은 없다고 생각한다. 연구 목표에 맞 는 모델을 선택하는 것이 가장 이상적이며 경우에 따라 단순 한 모델이 가장 적합할 수도 있다. 방대한 후각관련 기초연구 의 결과들이 보고되고 있는 것에 비해 아직 임상에서 후각소 실 환자들에게 도움을 줄 수 있는 방법이 많지 않은 것이 사 실이지만 지속적으로 중개연구(translational research) 결과 들이 축적되면 후각소실에 대한 치료도 큰 발전이 있을 것으 로 생각한다.

\section{REFERENCES}

1) Fokkens WJ, Lund VJ, Mullol J, Bachert C, Alobid I, Baroody F, et al. EPOS 2012: European position paper on rhinosinusitis and nasal polyps 2012. A summary for otorhinolaryngologists. Rhinology 2012;50(1):1-12.

2) Delank KW, Stoll W. Olfactory function after functional endoscopic sinus surgery for chronic sinusitis. Rhinology 1998;36(1):15-9.

3) Jiang RS, Lu FJ, Liang KL, Shiao JY, Su MC, Hsin CH, et al. Olfactory function in patients with chronic rhinosinusitis before and after functional endoscopic sinus surgery. Am J Rhinol 2008;22 (4):445-8

4) Raviv JR, Kern RC. Chronic rhinosinusitis and olfactory dysfunction. Adv Otorhinolaryngol 2006;63:108-24.

5) Raviv JR, Kern RC. Chronic sinusitis and olfactory dysfunction. Otolaryngol Clin North Am 2004;37(6):1143-57, v-vi.

6) Yee KK, Pribitkin EA, Cowart BJ, Vainius AA, Klock CT, Rosen
D, et al. Neuropathology of the olfactory mucosa in chronic rhinosinusitis. Am J Rhinol Allergy 2010;24(2):110-20.

7) Lee SH, Lim HH, Lee HM, Park HJ, Choi JO. Olfactory mucosal findings in patients with persistent anosmia after endoscopic sinus surgery. Ann Otol Rhinol Laryngol 2000;109(8 Pt 1):720-5.

8) Moran DT, Rowley JC 3rd, Aiken GR, Jafek BW. Ultrastructural neurobiology of the olfactory mucosa of the brown trout, Salmo trutta. Microsc Res Tech 1992;23(1):28-48.

9) Chuah MI, Zheng DR. Olfactory marker protein is present in olfactory receptor cells of human fetuses. Neuroscience 1987;23(1):363-70.

10) Kern RC, Pitovski DZ. Localization of 11 beta-hydroxysteroid dehydrogenase: specific protector of the mineralocorticoid receptor in mammalian olfactory mucosa. Acta Otolaryngol 1997;117(5): 738-43.

11) Leung CT, Coulombe PA, Reed RR. Contribution of olfactory neural stem cells to tissue maintenance and regeneration. Nat Neurosci 2007;10(6):720-6.

12) Carter LA, MacDonald JL, Roskams AJ. Olfactory horizontal basal cells demonstrate a conserved multipotent progenitor phenotype. J Neurosci 2004;24(25):5670-83.

13) Chen M, Tian S, Yang X, Lane AP, Reed RR, Liu H. Wnt-responsive Lgr5+ globose basal cells function as multipotent olfactory epithelium progenitor cells. J Neurosci 2014;34(24):8268-76.

14) Hurtt ME, Thomas DA, Working PK, Monticello TM, Morgan KT. Degeneration and regeneration of the olfactory epithelium following inhalation exposure to methyl bromide: pathology, cell kinetics, and olfactory function. Toxicol Appl Pharmacol 1988;94(2):311-28.

15) Holbrook EH, Iwema CL, Peluso CE, Schwob JE. The regeneration of P2 olfactory sensory neurons is selectively impaired following methyl bromide lesion. Chem Senses 2014;39(7):601-16.

16) Bakos SR, Schwob JE, Costanzo RM. Matrix metalloproteinase-9 and -2 expression in the olfactory bulb following methyl bromide gas exposure. Chem Senses 2010;35(8):655-61.

17) Jang W, Youngentob SL, Schwob JE. Globose basal cells are required for reconstitution of olfactory epithelium after methyl bromide lesion. J Comp Neurol 2003;460(1):123-40.

18) Schwob JE, Youngentob SL, Mezza RC. Reconstitution of the rat olfactory epithelium after methyl bromide-induced lesion. J Comp Neurol 1995;359(1):15-37.

19) Youngentob SL, Schwob JE, Sheehe PR, Youngentob LM. Odorant threshold following methyl bromide-induced lesions of the olfactory epithelium. Physiol Behav 1997;62(6):1241-52.

20) Dehnhard M, Bernal-Barragan H, Claus R. Rapid and accurate highperformance liquid chromatographic method for the determination of 3-methylindole (skatole) in faeces of various species. J Chromatogr 1991;566(1):101-7.

21) Schiestl FP, Roubik DW. Odor compound detection in male euglossine bees. J Chem Ecol 2003;29(1):253-7.

22) Turk MA, Flory W, Henk WG. Chemical modulation of 3-methylindole toxicosis in mice: effect on bronchiolar and olfactory mucosal injury. Vet Pathol 1986;23(5):563-70.

23) Owens JG, James RA, Moss OR, Morgan KT, Bowman JR, Struve $\mathrm{MF}$, et al. Design and evaluation of an olfactometer for the assessment of 3-methylindole-induced hyposmia. Fundam Appl Toxicol 1996; 33(1):60-70.

24) Peele DB, Allison SD, Bolon B, Prah JD, Jensen KF, Morgan KT. Functional deficits produced by 3-methylindole-induced olfactory mucosal damage revealed by a simple olfactory learning task. Toxicol Appl Pharmacol 1991;107(2):191-202.

25) Miller MA, Kottler SJ, Ramos-Vara JA, Johnson PJ, Ganjam VK, Evans TJ. 3-methylindole induces transient olfactory mucosal injury in ponies. Vet Pathol 2003;40(4):363-70.

26) Kim HY, Kim JH, Dhong HJ, Kim KR, Chung SK, Chung SC, et al. Effects of statins on the recovery of olfactory function in a 
3-methylindole-induced anosmia mouse model. Am J Rhinol Allergy 2012;26(2):e81-4

27) Kim JW, Hong SL, Lee CH, Jeon EH, Choi AR. Relationship between olfactory function and olfactory neuronal population in C57BL6 mice injected intraperitoneally with 3-methylindole. Otolaryngol Head Neck Surg 2010;143(6):837-42.

28) Miller MA, O'Bryan MA. Ultrastructural changes and olfactory deficits during 3-methylindole-induced olfactory mucosal necrosis and repair in mice. Ultrastruct Pathol 2003;27(1):13-21.

29) Kern RC, Conley DB, Haines GK 3rd, Robinson AM. Pathology of the olfactory mucosa: implications for the treatment of olfactory dysfunction. Laryngoscope 2004;114(2):279-85.

30) Heilmann S, Huettenbrink KB, Hummel T. Local and systemic administration of corticosteroids in the treatment of olfactory loss. Am J Rhinol 2004;18(1):29-33.

31) Lane AP, Zhao H, Reed RR. Development of transgenic mouse models for the study of human olfactory dysfunction. Am J Rhinol 2005;19 (3):229-35.

32) Lane AP, Turner J, May L, Reed R. A genetic model of chronic rhinosinusitis-associated olfactory inflammation reveals reversible functional impairment and dramatic neuroepithelial reorganization. J Neurosci 2010;30(6):2324-9.

33) Feldmann M, Maini RN. The role of cytokines in the pathogenesis of rheumatoid arthritis. Rheumatology (Oxford) 1999;38 Suppl 2:3-7.

34) Kollias G, Douni E, Kassiotis G, Kontoyiannis D. On the role of tumor necrosis factor and receptors in models of multiorgan failure, rheumatoid arthritis, multiple sclerosis and inflammatory bowel disease. Immunol Rev 1999;169:175-94.

35) Barker V, Middleton G, Davey F, Davies AM. TNFalpha contributes to the death of NGF-dependent neurons during development. Nat Neurosci 2001;4(12):1194-8.

36) Scherbel U, Raghupathi R, Nakamura M, Saatman KE, Trojanowski JQ, Neugebauer E, et al. Differential acute and chronic responses of tumor necrosis factor-deficient mice to experimental brain injury. Proc Natl Acad Sci U S A 1999;96(15):8721-6.

37) Zúñiga-Pflücker JC, Jiang D, Lenardo MJ. Requirement for TNFalpha and IL-1 alpha in fetal thymocyte commitment and differentiation. Science 1995;268(5219):1906-9.

38) Suzuki Y, Farbman AI. Tumor necrosis factor-alpha-induced apoptosis in olfactory epithelium in vitro: possible roles of caspase 1 (ICE), caspase 2 (ICH-1), and caspase 3 (CPP32). Exp Neurol 2000;165(1): $35-45$.

39) Hua ZC, Ding X. cDNA cloning and heterologous expression of mouse CYP2G1. Ann N Y Acad Sci 1998;864:309-12.

40) Roet KC, Verhaagen J. Understanding the neural repair-promoting properties of olfactory ensheathing cells. Exp Neurol 2014;261:594609

41) Chou RH, Lu CY, Wei-Lee, Fan JR, Yu YL, Shyu WC. The potential therapeutic applications of olfactory ensheathing cells in regenerative medicine. Cell Transplant 2014;23(4-5):567-71.

42) Ekberg JA, St John JA. Crucial roles for olfactory ensheathing cells and olfactory mucosal cells in the repair of damaged neural tracts. Anat Rec (Hoboken) 2014;297(1):121-8.

\section{정답 및 해설}

답 (2)

해 설 환자는 문진 및 산소 포화도 모니터링 상 central apnea에 의한 hypoventilation이 의심되는 상태이므로 central apnea 진단을 위해 수면다원검사 시행 시 nasal and oral airflow에 대한 변화와 가슴 및 복부의 호흡 노력에 대한 변화를 유의 해서 관찰해야 한다.

Reference: Cumming's Otolaringology Head \& Neck Surgery Fifth edition. Philadelphia, PA: Mosby Elsevier;2010. p.255, 263.

(4)

해 설 면역 요법은 집먼지 진드기, 꽃가루, 고양이 항원, Alternaria, Cladosporium 등 일부 곰팡이에 대하여 효과가 입증된 상 태이며 4세 이상의 소아에서 제한적으로 이용된다. 주로 환경요법, 약물요법에 효과가 없거나 부작용이 심할 때 이용되며, 증상이 연중 두 계절 혹은 6개월 이상 지속되고, 증상과 항원에 대한 양성 피부 반응 혹은 혈청 특이항체가 확실할 때 시 행한다.

Reference: 대한이비인후과학회. 이비인후과-두경부외과학. 서울: 일조각;2009. p.1102-3. 